\title{
A NECESSIDADE DA PREMISSA DIALÓGICA COMO INTERESSE PROCESSUAL NOS CONFLITOS COLETIVOS
}

\author{
THE NECESSITY OF THE DIALOGICAL PREMISE AS A PROCEDURAL INTEREST IN \\ COLLECTIVE CONFLICTS
}

\section{Gisele Santos Fernandes Goes}

Doutora (PUC-SP). Mestre (UFPA). Especialista em Direito Civil e Processual Civil. Professora da UFPA. Secretária-adjunta da Região Norte e membro do Instituto Brasileiro de Direito Processual (IBDP), membro do Instituto Ibero-Americano de Direito Processual (IIDP). Coordenadora Nacional de

2. ${ }^{\text {grau }(M P T) ~ e ~ P r o c u r a d o r a ~ R e g i o n a l ~ d o ~ t r a b a l h o ~(P R T ~ 8 . ~}{ }^{\text {a }}$ Região).

E-mail: gisagoes@hotmail.com. https://orcid.org/0000-0002-2104-2889.

\section{Sandoval Alves da Silva}

Doutor e mestre em Direito (UFPA), na linha de pesquisa sobre constitucionalismo, democracia e direitos humanos. Procurador do trabalho lotado na Procuradoria Regional do Trabalho da $8 .^{a}$ Região, vice-procurador-chefe da $8 .^{a}$ Região. Professor da UFPA, na graduação e na pós-graduação em Direito. Membro da International Association of

Procedural Law (IAPL), membro do Instituto Ibero-Americano de Direito Processual (IIDP). Associado da Associação Norte e Nordeste de Professores de Processo (ANNEP). Líder do Grupo de Pesquisa "Comunidade, conflitos, problemas, insatisfações sociais e o estudo sobre a paz" (CNPq).

E-mail: sandovalalves8@gmail.com. https://orcid.org/0000-0002-1795-2281.

\section{Thiago Vasconcellos Jesus}

Mestrando em Direito (UFPA). Especialização em Direito Público (UGF). Graduação em Direito (UFPA). Procurador do Estado do Pará. Membro do Grupo de Pesquisa "Comunidade, conflitos, problemas, insatisfações sociais e o estudo sobre a paz" (CNPq). Professor de Processo Civil II da Escola Superior Madre Celeste (ESMAC).

E-mail: thiagojesus1@ @otmail.com. https://orcid.org/0000-0001-5186-9206

Recebido em: 17/07/2020

Aprovado em: 14/12/2020

RESUMO: A premissa dialógica é um instituto fundamental para garantir o acesso à justiça e a tutela nos conflitos coletivos. Apontam-se neste estudo possíveis instrumentos dialógicos para viabilizar a persuasão racional dos envolvidos e a construção argumentativa por acordo pelo Ministério Público, gradualmente e sem o monopólio da jurisdição, para decidir centralizadamente a controvérsia. Analisando-se a doutrina e a jurisprudência, bem como casos concretos no Estado do Pará, questiona-se se o eventual afastamento da premissa dialógica autocompositiva pode configurar ausência de interesse processual e ausência da secundariedade da jurisdição na tutela dos direitos coletivos. Conclui-se que é possível o controle judicial, quando não se prestigia o diálogo na solução dos conflitos, especialmente em demandas de acentuada conflituosidade e intensa complexidade. 
Palavras-chave: Instrumentos dialógicos. Ministério Público. Direitos fundamentais. Interesse. Controle judicial.

ABSTRACT: The dialogical premise is a fundamental institute for protection in collective conflicts and access to justice. Possible dialogical instruments will be demonstrated to enable the rational persuasion of those involved and argumentative construction by agreement by the Public Ministry gradually and without the monopoly of jurisdiction to centrally decide the controversy. Analyzing the doctrine and the jurisprudence, as well as concrete cases in the State of Pará, we tried to answer the following question: can any departure from the self-composing dialogical premise constitute an absence of procedural interest and of the secondary jurisdiction in the protection of collective rights? It is concluded that judicial control is possible when there is no prestige in the dialogue in the solution of conflicts, in view of the potential benefits of plural and rational deliberation with the protagonism of those involved in the solution by agreement, especially in demands of marked conflict and intense complexity.

Keywords: Dialogical instruments. Public Ministry. Fundamental rights. Interest. Judicial control.

SUMÁRIO: Introdução. $1 \mathrm{O}$ acesso à justiça e a premissa dialógica. 2 Possíveis instrumentos dialógicos para a concretização de direitos fundamentais pelo Ministério Público. 3 A premissa dialógica pré-processual nas ações coletivas e a ausência de interesse na judicialização: casos concretos no Estado do Pará. Conclusão. Referências.

\section{INTRODUÇÃO}

Considerando a complexidade dos conflitos de natureza coletiva, é fundamental reconhecer a importância não só dos instrumentos existentes para a tutela dos direitos atingidos, mas também da adequada utilização de todos os mecanismos aptos a alcançar a ordem jurídica justa com a concretização dos direitos fundamentais.

O presente artigo parte da premissa de que deve haver resistência à pretensão material do autor de que daí surja ou apareça o interesse processual para agir e fique demonstrado o fracasso da primariedade autocompositiva na tutela coletiva, principalmente por meio do diálogo institucional, requerendo-se a consequente secundariedade da jurisdição. Nessa esteira, analisarse-á a premissa dialógica como instrumento de garantia do acesso à justiça e da concretização dos direitos fundamentais.

Em seguida, indicam-se os possíveis instrumentos dialógicos para a tutela de direitos fundamentais de que dispõe o Ministério Público (MP), dando-se ênfase ao instrumento da recomendação ministerial.

Em seção própria, foram estudados três casos concretos judicializados pelo Ministério Público, envolvendo o Estado do Pará em conflitos coletivos sobre políticas públicas desmatamento, saneamento básico e obras de trânsito e de transporte. Examina-se um eventual afastamento da premissa dialógica extrajudicial como elemento de aferição do interesse processual e da secundariedade da jurisdição, com suas possíveis consequências.

Num esforço metodológico para aliar razões epistemológicas e práticas, buscar-se-á responder ao seguinte questionamento: um eventual afastamento da premissa dialógica autocompositiva pode configurar ausência de interesse processual e da secundariedade da jurisdição na tutela dos direitos coletivos?

Ao final, à luz de estudos doutrinários, do entendimento jurisprudencial e da avaliação de três casos concretos no âmbito do Estado do Pará, indicam-se apontamentos conclusivos quanto à eventual ausência de interesse de agir nas ações coletivas, notadamente quando se afasta a premissa 
dialógica para o acesso à justiça, conforme precedentes do Supremo Tribunal Federal (STF), do Superior Tribunal de Justiça (STJ) e do Tribunal de Justiça do Pará (TJPA).

\section{O ACESSO À JUSTIÇA E A PREMISSA DIALÓGICA}

Destaque-se que o objetivo do direito não é a eficiência, é a justiça. O conceito de justiça abrange um conjunto de valores mais ricos e profundos do que a simples eficiência, embora deva incluir algumas necessárias considerações sobre resultados eficientes. Por isso, o direito deve ser concebido como justiça, ainda que se reconheça que parte da justiça tenha relação com resultados eficientes. Vale insistir no fato de que não devemos tentar equilibrar as duas coisas, devemos, antes, fazer uma escolha, optando notadamente pela justiça (FISS, 2005, p. 42).

Sobre o acesso à justiça, importa dizer que o Judiciário é o órgão em que os conflitos deveriam terminar e não começar (como ocorre no Brasil). Cabe questionar se o Judiciário é a melhor forma de resolução de alguns conflitos (RAY; CLARE, 1985). De fato, cumpre destacar o necessário acesso à ordem jurídica justa e a existência de um sistema de múltiplas portas para efetivar a solução dos conflitos (CRESPO, 2012; NOGUEIRA; NOGUEIRA, 2018).

Aliás, é reconhecida a dificuldade institucional do Judiciário para solucionar problemas estruturais relativos às políticas públicas e ainda para alcançar a eventual execução de suas decisões. Assim, são recomendáveis o diálogo interinstitucional e a contribuição de profissionais com expertise em determinados temas complexos para que acompanhem e avaliem as decisões judiciais sobre a implementação de políticas públicas (SARMENTO, 2016). Defendem-se, pois, a ampliação procedimental e o avanço para um "novo modelo de processo, mais democrático, mais participativo, mais policentrista", menos unicentrista (MACEDO; RODRIGUES, 2017).

$\mathrm{O}$ acesso à justiça é um direito social. Caso submetido ao Judiciário, a ele caberá tornar os direitos sociais concretizáveis, sendo "necessária uma concepção processual de justiça social no acesso à justiça, pois de nada adianta garantir materialmente um direito se processualmente não se garante o acesso à ordem jurídica justa" (SILVA, 2017, p. 1085).

Para a concretização dos direitos fundamentais - entre os quais se inserem os sociais - e, consequentemente, do acesso à justiça, cumpre prestigiar o sistema de integração e de cooperação entre os órgãos que visam o interesse coletivo, que defendem o critério material de justiça. Esses órgãos devem cumprir seu dever jurídico de atendimento dos interesses coletivos, não se admitindo, pois, a criação de óbices à concretização dos direitos fundamentais por parte do Judiciário (SILVA, 2007, p. 203-204).

Cumpre interpretar o princípio da inafastabilidade do acesso jurisdicional não só como acesso formal aos órgãos do Judiciário, mas, principalmente, como acesso à justiça ${ }^{1}$ que assegure efetiva e tempestiva proteção contra qualquer forma de denegação de justiça e também o acesso à ordem jurídica justa (SALLES, 2003, p. 47 e p. 49).

Um instituto que pode assegurar o acesso à ordem jurídica justa é o acordo. $\mathrm{O}$ acordo viabiliza a construção de uma solução extraprocessual "que atenda mais propriamente à efetividade dos direitos e interesses coletivos envolvidos, especificando, inclusive, os detalhes para sua implementação de modo a garantir maior resolutividade à solução jurídica encontrada" (GAVRONSKI, 2010, p. 260). Os instrumentos de concretização do direito por meio da negociação informal facilitam a formação do acordo. É possível realizar várias reuniões conduzidas por debates orais sem o compromisso da irreversibilidade, de preclusões ou confissões oponíveis juridicamente, o que é vantajoso para os envolvidos por causa da celeridade e do efetivo cumprimento do acordo (GAVRONSKI, 2010, p. 266).

Aliás, o cerne do acesso à justiça consiste em sua realização no contexto em que se inserem

1 Registre-se, a esse respeito, que o atendimento das necessidades humanas pode ser feito, entre outros atores, pelo Estado, que assume o dever da concretização dos direitos sociais para atender às necessidades humanas, à luz, evidentemente, de uma concepção social, que busca o alcance do bem-estar de cada um (SILVA, 2016, p. 59 e p. 63).

Revista de Direito Brasileira | Florianópolis, SC | v. 27 | n. 10 | p.281-299 | Set./Dez. 2020 
as pessoas e não em possibilitar que todos possam ir à Corte. No processo democrático, o acesso à justiça desempenha um relevante papel ao habilitar o cidadão a tutelar seus interesses e ao possibilitar à sociedade a composição pacífica de conflitos. Os princípios que informam o acesso à justiça são: acessibilidade, operosidade, utilidade e proporcionalidade. $\mathrm{O}$ Estado deve oferecer múltiplas possibilidades para a solução dos conflitos, e a coexistência de todos os métodos acessíveis contribui para a configuração de um sistema pluriprocessual eficiente e adequado para a composição efetiva das controvérsias e a pacificação social adequada (TARTUCE, 2019, p. 6972 e p. 84$)^{2}$.

Nessa esteira, compreende-se que o acesso à justiça não significa apenas acesso ao Judiciário, visto que o acesso à justiça implica acesso à cidadania e à participação democrática nos rumos da sua própria vida em comunidade (SILVA, 2017).

Nesse sentido, existem vários métodos reconhecidos pelo Estado para a solução de conflitos, tais como a conciliação endo ou extraprocessual, a autocomposição e, excepcionalmente, a autotutela, sendo "melhor deixar que o Estado só intervenha, mediante o exercício da jurisdição, quando tais métodos não tiverem surtido efeito" (CINTRA; GRINOVER; DINAMARCO, 2005, p. 142-143). A propósito, as soluções não jurisdicionais têm ganhado corpo na pacificação, visto que o formalismo do processo toma tempo e apresenta custos, o que representa possíveis óbices à efetividade na pacificação. Esses obstáculos não são enfrentados pelos mecanismos não jurisdicionais, que têm as características de desformalização, celeridade e delegalização (CINTRA; GRINOVER; DINAMARCO, 2005, p. 27-29).

Uma das características da jurisdição é a lide, notadamente "quando se trata de pretensões insatisfeitas que poderiam ter sido satisfeitas pelo obrigado" (CINTRA; GRINOVER; DINAMARCO, 2005, p. 142). E a contraposição de interesses justificaria a substituição dos sujeitos em conflito pelo Estado ${ }^{3}$.

Ao lado disso, vale destacar a característica da secundariedade da jurisdição, porque o Estado realiza por meio dela coativamente uma atividade que deveria ter sido primariamente exercida pelos protagonistas do conflito de maneira pacífica e espontânea. Assim, a atividade exercida pelo Estado afigura-se como secundária para os próprios sujeitos da relação jurídica submetida à decisão jurisdicional (CALAMANDREI, 1945, p. 20; THEODORO JÚNIOR, 2017, p. 140).

Registre-se, ainda, que "haverá interesse-necessidade quando a realização do direito material afirmado pelo demandante não puder se dar independentemente do processo" (CÂMARA, 2018, p. 39).

A propósito, vale destacar que existem elementos expressos de viabilização do diálogo, inclusive após a judicialização precipitada, notadamente a previsão de oitiva prévia, legalmente prevista no artigo $2 .^{\circ}$ da Lei n. ${ }^{\circ} 8.437 / 1992$, ou a audiência de conciliação ou de mediação expressa

\footnotetext{
2 São óbices no acesso ao Poder Judiciário: a) dificuldade de acesso pelos custos ou pelas condições pessoais das partes; b) dificuldade de proteção de certos interesses, tanto por sua conotação difusa na sociedade quanto por sua dimensão diminuta se considerada individualmente, a ponto de desestimular a atuação dos lesados; c) preocupante inter-relacionamento entre as barreiras existentes como fator que dificultava a adoção de medidas isoladas para sanar os problemas. A primeira onda renovatória de universalização do acesso focou a necessidade de propiciar acesso aos marcados pela vulnerabilidade econômica. Já a segunda buscou reformar os sistemas jurídicos para dotá-los de meios atinentes à representação jurídica dos interesses "difusos", atuando especialmente sobre conceitos processuais clássicos para adaptá-los à adequada concepção de processo coletivo. A terceira onda preconizou uma concepção mais ampla de acesso à justiça, com uma especial atenção ao conjunto geral de instituições e mecanismos, pessoas e procedimentos utilizados para processar e prevenir disputas nas sociedades (TARTUCE, 2019, p. 84-85).

3 A esse respeito, embora inicialmente considerada característica inerente à secundariedade da jurisdição (CÂMARA, 2013, p. 82), a primariedade de tentativa de solução direta e autônoma pelos protagonistas do conflito é importante para a configuração da característica acidental da jurisdição, primariedade agora enquadrada como lide, porque também existe jurisdição nas ações necessárias, como na anulação de casamento, cujo resultado só pode ser efetivado por meio de processo jurisdicional (CÂMARA, 2018, p. 33).
}

Revista de Direito Brasileira | Florianópolis, SC | v. 27 | n. 10 | p.281-299 | Set./Dez. 2020 
no artigo 334 do Código de Processo Civil (CPC). Assim, eventual manifestação processual pleiteando a dispensa desse diálogo pela parte autora de uma ação judicial coletiva não corresponde ao interesse processual, tampouco à secundariedade da jurisdição, visto que a previsão legal exige a manifestação de todos os envolvidos para a dispensa dessa audiência (art. 334, § 4. ${ }^{\circ}$, I, do CPC) ${ }^{4}$.

Deve-se observar que a importância autocompositiva pré-processual do diálogo para a demanda não precisa ser expressa processualmente, visto que a omissão na petição inicial em relação à oportunidade para exercer a autocomposição em juízo (audiência de conciliação ou de mediação) é interpretada como silêncio eloquente, no sentido de manifestação de concordância, tornando prescindível a emenda da inicial, conforme Enunciado n. ${ }^{\circ} 11$ do TJPA ${ }^{5}$.

Ao lado disso, vale destacar o entendimento do STF no Recurso Extraordinário (RE) n. ${ }^{\circ}$ 631.240 submetido à Repercussão Geral, ao julgar questão envolvendo benefício previdenciário perante o Instituto Nacional de Seguridade Social (INSS). A conclusão foi no rumo de que é necessário o requerimento administrativo prévio para a configuração do interesse de agir, assentando a compatibilidade da instituição de condições para o regular exercício do direito de ação com o artigo 5. ${ }^{\circ}, \mathrm{XXXV}$, da Constituição da República Federativa do Brasil (CRFB). Assim, concluiu o STF que, para se caracterizar a presença de interesse em agir, é preciso haver a necessidade de ir a juízo ${ }^{6}$.

Considerando-se a conclusão do RE $n .^{\circ}$ 631.240, registre-se a obediência pelas instâncias ordinárias ao que ficou decidido no referido precedente. Assim, a 2. ${ }^{a}$ Vara do Juizado Especial de Fazenda Pública em Belém (PA) ${ }^{7}$ julgou que o entendimento do RE n. ${ }^{0} 631.240$ é aplicável a outras hipóteses em que seja plenamente viável o deferimento do pedido do cidadão, em sede administrativa. Ainda nessa sentença, citou-se a recém-criada Lei Complementar (LC) n. ${ }^{\circ}$ $121 / 2019$, cujo objetivo é reduzir a litigiosidade perante o Poder Judiciário a partir da instituição da Câmara de Negociação, e concluiu-se que a ausência de comprovação de prévia tentativa administrativa, ou a inexistência de prazo excessivo sem manifestação pelo réu, implicava o indeferimento da inicial, nos termos do artigo 485, VI, do $\mathrm{CPC}^{8}$.

4 Lei n. ${ }^{\circ}$ 8.437/1992: "Art. 2. ${ }^{\circ}$ No mandado de segurança coletivo e na ação civil pública, a liminar será concedida, quando cabível, após a audiência do representante judicial da pessoa jurídica de direito público, que deverá se pronunciar no prazo de setenta e duas horas". CPC/2015: "Art. 334. Se a petição inicial preencher os requisitos essenciais e não for o caso de improcedência liminar do pedido, o juiz designará audiência de conciliação ou de mediação com antecedência mínima de 30 (trinta) dias, devendo ser citado o réu com pelo menos 20 (vinte) dias de antecedência $[\ldots] \S 2 .^{\circ}$ Poderá haver mais de uma sessão destinada à conciliação e à mediação, não podendo exceder a 2 (dois) meses da data de realização da primeira sessão, desde que necessárias à composição das partes".

5 Enunciado 11: "A omissão na petição inicial quanto à audiência de conciliação ou mediação é interpretada como manifestação de concordância, tornando desnecessária a intimação para emenda".

6 STF (Tribunal Pleno). RE 631240. Relator: Min. Roberto Barroso. Julgamento: 03/09/2014. Acórdão Eletrônico Repercussão Geral. Mérito Dje 220. Divulgação: 07/11/2014. Publicação: 10/11/2014. A esse respeito, vale destacar que a força vinculante formal do Acórdão que foi submetido à Repercussão Geral tem fundamento no artigo 102, § 3. ${ }^{\circ}$, da CRFB, reforçado no artigo 927, III, do CPC (MAGALHÃES; SILVA, 2012, p. 85-89). Ainda quanto à força vinculante, vale registrar que o STF já reconheceu ser "constitucional lei ordinária que define como de eficácia vinculante os julgamentos definitivos de mérito proferidos pelo Supremo Tribunal Federal em ação direta de inconstitucionalidade". O caso concreto consistiu na discussão sobre a constitucionalidade do artigo 28, parágrafo único, da Lei n. ${ }^{\circ}$ 9.868/1999 (STF (Tribunal Pleno). Rcl 1.880/SP. Relator: Min. Maurício Corrêa. Julgamento: 07/11/2002. Publicação: DJ 19/03/2004 PP-00017 EMENT VOL-02144-02 PP-00284).

7 No Processo n. ${ }^{\circ}$ 0862000-45.2019.814.0301, sentença de 27 de novembro de 2019.

8 Assim, ainda que a Repercussão Geral não tivesse força vinculante formal conforme o artigo 102, § $3 .^{\circ}$, da CRFB e o artigo 927, III, do CPC, a sua aplicação repetida em casos posteriores demonstraria um efeito vinculante material (MAGALHÃES; SILVA, 2012, p. 93-94). Porém, o argumento do efeito vinculante material não se faz necessário no presente caso, pois ele já é formalmente garantido pelo CPC (art. 927, III) e em obediência ao mandamento constitucional (art. 102, § 3. ${ }^{\circ}$ ). A propósito, vale destacar alguns julgados do Superior Tribunal de Justiça que obedeceram ao referido RE n. ${ }^{\circ}$ 631.240: STJ (3. Turma). AgRg no REsp 936.574/SP. Relator: Min. Paulo de Tarso Sanseverino. Julgamento: 02/08/2011. Publicação: DJe 08/08/2011; STJ. REsp 1.383.566/RS. Relator: Min. Herman Benjamin. Publicação: 23/08/2013; STJ. AgRg no REsp 1.399.337/SC. Relator: Min. Herman Benjamin. Publicação:

Revista de Direito Brasileira | Florianópolis, SC | v. 27 | n. 10 | p.281-299 | Set./Dez. 2020 
Dessa forma, observam-se os possíveis benefícios proporcionados pelo diálogo deliberativo, autônomo e plural como instrumento para garantir o acesso à ordem jurídica justa, o afastamento desse diálogo pré-processual, tal como nos casos de precipitada judicialização ${ }^{9}$, implicando o afastamento do interesse-necessidade e da secundariedade da jurisdição.

\section{POSSÍVEIS INSTRUMENTOS DIALÓGICOS PARA A CONCRETIZAÇÃO DE DIREITOS FUNDAMENTAIS PELO MINISTÉRIO PÚBLICO}

Conforme destacado acima, deve ser demonstrado o interesse processual, que deve levar em consideração determinadas premissas, entre as quais a possível solução dialógica e autocompositiva, tendo em vista a tutela dos direitos então discutidos.

É importante adotar mecanismos de comunicação (KAUFMANN; HASSEMER, 2008, p. 29), de debate e de diálogo (RODRÍGUEZ-GARAVITO, 2011), sendo a procedimentalização primordialmente uma obrigação estatal, além de um direito do cidadão (ABRAMOVICH, 2005, p. 205). De fato, o diálogo é fundamental para a concretização do programa jurídico-político estabelecido pela Constituição ou pelos pactos de direitos humanos, dadas as limitações do Judiciário para projetar políticas públicas. A informação é um instrumento imprescindível para tornar efetivo o controle via cidadão das políticas públicas na área econômica e social, ao mesmo tempo que contribui para a vigilância, por parte do próprio Estado, do grau de efetividade dos direitos econômicos, sociais e culturais (ABRAMOVICH, 2005, p. 209 e p. 212).

O diálogo com a articulação dos diferentes atores é uma das chaves para a resolução do caso, em especial em questões complexas, contribuindo para enfrentar eventuais deficiências institucionais - as políticas de Estado ou as situações sociais que estão na raiz do conflito (ou melhor, dos conflitos, problemas e insatisfações sociais). As estratégias bem-sucedidas exigem mobilização e ativismo dos protagonistas do conflito. Não se pode esquecer a dificuldade de implementação de decisões judiciais (até mais do que a obtenção de decisão favorável, o que sugere ordens dinâmicas, contínuas, graduais e progressivas). É necessário ter cautela para evitar o uso excessivo do sistema judicial, que acaba impedindo as chances de ação política ou de desenvolvimento gradual da jurisprudência (ou precedentes). Por outro lado, é preciso sempre buscar um remédio efetivo que pode não ser judicial, mas dialógico, no espaço político e de políticas públicas dos Estados (LANGFORD, 2009, p. 108 e p. 121-122) ${ }^{10}$.

A atuação extraprocessual é não só possível, como principalmente recomendada, com precedente à configuração do conflito e mais efetiva porque baseada na construção plural e argumentativa do acordo, sem prejuízo da celeridade e da qualidade, com baixo custo, resolutividade e satisfação das partes (ou dos sujeitos envolvidos) (GAVRONSKI, 2010, p. 272 e p. 433; SALLES, 2006, p. 781-783).

Leciona-se que a tutela jurisdicional se relaciona com a interpretação da inafastabilidade, devendo-se avaliar qual a tutela adequada: nem só judicial, nem só extraprocessual, sendo necessário justificar a judicialização como uma qualificação do interesse de agir (GAVRONSKI,

07/11/2014. No mesmo sentido, o TJPA nos seguintes julgados: TJPA (1. Turma de Direito Privado). 2019.0143475523, não informado. Relator: Constantino Augusto Guerreiro. Julgamento: 16/04/2019. Publicação: 16/04/2019; TJPA (1. Câmara Cível Isolada). 2016.04776818-95, não informado. Relator: Leonardo de Noronha Tavares. Julgamento: 26/01/2017. Publicação: 26/01/2017; TJPA (Turma Recursal Permanente). 2019.01670610-73, 29.565. Relatora: Ana Angelica Pereira Abdulmassih. Julgamento: 10/04/2019. Publicação: 03/05/2019.

9 Registre-se a ineficiência (ou melhor, a falta de efetividade na tutela dos direitos fundamentais) da judicialização das ações coletivas, que se revelam falhas na representatividade adequada, em especial, dos titulares dos direitos individuais de massa, numa imperfeição da relação entre o titular do direito a ser tutelado e o condutor do processo judicial de defesa do respectivo direito (RODRIGUES, 2017, p. 107-114).

10 Registre-se a possibilidade de que não só o primeiro setor (Estado), mas também o segundo (mercado) e o terceiro setores proporcionem o atendimento das necessidades humanas, com fundamento na eficácia dos direitos humanos entre os particulares (SILVA, 2016, p. 63).

Revista de Direito Brasileira | Florianópolis, SC | v. 27 | n. 10 | p.281-299 | Set./Dez. 2020 
2010, p. 235; SALLES, 2006, p. 790) e da secundariedade da jurisdição, salvo no caso das ações necessárias.

A propósito, é importante priorizar a solução do conflito, de maneira que se preserve o relacionamento entre os envolvidos. De fato, há que se evitar a destruição de relacionamentos ou ranhuras que eventualmente prejudiquem a engrenagem dialógica e conciliatória na pacificação dos litígios (OSNA, 2017, p. 46).

Existem custos inevitáveis do processo, além de incertezas jurídicas e uma postura adversarial típica na seara judicial, o que muitas vezes não é adequado à solução do conflito. Recomenda-se a postura cooperativa, com um debate policêntrico, e a análise da proporcionalidade, com a utilização dos métodos necessários, adequados e proporcionais em sentido estrito. Nesses termos, há que se analisar a possibilidade material do processo se observada a panprocessualidade a fim de que, além da utilização de meios adequados e imprescindíveis (necessários), os benefícios superem os prejuízos (OSNA, 2017, p. 65-144).

Ao lado disso, a complexidade de megaconflitos (sobretudo os de políticas públicas) recomenda a busca da solução consensual porque mais célere, transparente, democrática e pedagógica em uma sociedade marcada por múltiplos direitos e interesses, que ora convergem, ora divergem entre si. A solução consensual possivelmente é alcançada por meio de um diálogo democrático, sincero e respeitoso entre os envolvidos, munindo-se de informações técnicas de maneira cooperativa, com igualdade de chances e de oportunidades de sugestões para acomodar a pretensão de todos os sujeitos, mostrando-se tais caminhos qualitativamente muito mais adequados $^{11}$ do que a própria solução judicial (para além da provável demora na instrução probatória, custos e tempo para a solução do conflito), objetivando-se uma solução consensual (ou melhor, por acordo) justa e adequada (RODRIGUES, 2017, p. 136-137 e p. 146).

Sendo o processo coletivo estrutural uma espécie de processo de interesse público, envolve questões de fato e de direito de alta complexidade, que exigem um contínuo e intenso esforço cooperativo para assegurar um tratamento adequado ao litígio, admitindo-se a descentralização das atividades decisórias. Cumpre definir espaços de diálogo em que sejam exercidos o direito de influência e o dever de debates sobre as matérias de direito, buscando-se encontrar as alternativas comuns de consenso (ou melhor, de acordo), sem a redução da qualidade da decisão, e evitando-se recursos e eventual necessidade de execução, por meio de soluções combinadas de tutela coletiva para otimizar a tutela das pessoas e dos direitos de maneira justa, adequada e efetiva na resolução do conflito (ZANETI JR., 2019, p. 407-409).

À luz de estudos sobre meio ambiente, improbidade e liberdade ${ }^{12}$, indica-se uma desconstrução de duas premissas básicas: a da inegociabilidade e a da exclusividade da solução puramente adjudicatória do Estado a respeito dos conflitos que o envolvem. Sustenta-se o gradativo emprego de outros métodos resolutivos, entre os quais a mediação, a negociação e a conciliação

11 Quanto à expressão "meios alternativos", vale registrar a controvérsia doutrinária e a possível impropriedade técnica, notadamente porque pode configurar-se preconceituosa (prestigiando-se a via jurisdicional). Nos mesmos termos, a palavra "adequado" pode implicar igualmente presunçoso em relação à autocomposição (prestigiando-se a via autocompositiva, em detrimento da jurisdicional) (RODRIGUES, 2017, p. 146). De toda forma, cabe ao Estado criar métodos de solução de conflitos, tendo em vista a coexistência de todos os métodos acessíveis a fim de formar um sistema pluriprocessual eficiente e adequado para a real composição das controvérsias verificadas (TARTUCE, 2019, p. 187-190). Apesar de não se filiarem a um sistema de classificação que exclua os demais métodos de solução de conflito, as expressões "multiportas" ou "adaptado" são gradualmente aceitáveis, visto que não privilegiam ou discriminam qualquer forma de solução de conflitos e problemas.

12 Venturi questiona o que pode ser "negociável": a liberdade - com o sursis processual, a transação penal e a composição dos danos civis, previstas na Lei dos Juizados Especiais; o meio ambiente - daí os acordos, por exemplo, sobre créditos de carbono como instrumento de progressiva introdução de políticas ecológicas e desincentivo à poluição, o que gerou em 2014 aproximadamente noventa bilhões de dólares ao redor do mundo; a probidade administrativa - com a aplicabilidade analógica da delação premiada à improbidade, com a releitura do artigo $17, \S$ 1 . $^{\circ}$, da Lei n. ${ }^{\circ} 8.429 / 1982$ e a provável revogação do artigo 36, § 4. ${ }^{\circ}$, da Lei de Mediação (VENTURI, 2016). 
(VENTURI, 2016), ressalvando-se nesses casos as ações necessárias em que a primariedade já é exercida jurisdicionalmente.

A esse respeito, vale destacar que o poder do juiz não pode ser maior que o originalmente dos litigantes, não passando a atuação do juiz de um ajustamento de conduta dos demandantes à ordem jurídica, o que representa a substituição da decisão do juiz por um possível acordo deliberativo. De fato, propõe-se a alteração do "que" é indisponível para "como", "quando" e "quem" pode dispor dos interesses (SILVA, 2016, p. 258-262).

Cumpre observar os direitos a procedimentos entendidos como direitos a ações estatais positivas, direcionando-se ao Poder Público os direitos a uma determinada interpretação e aplicação concreta de normas procedimentais, que consistem em direitos essenciais a uma proteção jurídica efetiva. Notadamente o resultado do procedimento deve proteger efetivamente os direitos materiais dos interessados e dos titulares de direitos fundamentais submetidos à discussão (ALEXY, 2008, p. 488).

Para a concretização dialógica dos direitos sociais, os atos, normas e instrumentos devem estar concatenados. A estrutura procedimental compreende as seguintes fases: a) iniciativa, b) persuasão racional deliberativa ou de concretização ${ }^{13}$, c) aplicação ou realização e d) fiscalização ou controle (SILVA, 2016, p. 266).

Nesse contexto, além da possível flexibilização e autocomposição para determinados direitos ditos indisponíveis, ao Ministério Público - como legitimado na tutela coletiva (conforme o artigo 129, III, da CRFB e o artigo $5 .^{\circ}$, I e $\S 3 .^{\circ}$, da Lei n. ${ }^{\circ} 7.347 / 1985$ ) -, são asseguradas nas fases de iniciativa e de persuasão racional deliberativa: a) a notificação, forma de comunicação externa ministerial com a finalidade de cientificar alguém para comparecimento perante a instituição; b) a intimação, na qual se dá ciência de um ato praticado com a chance de reação; c) a inspeção, que viabiliza a fiscalização in loco para persuasão racional deliberativa no caso concreto, com livre acesso e possibilidade de requisição de força policial; d) a requisição, de cunho obrigatório, cujo descumprimento está sujeito à responsabilização criminal e cível (SILVA, 2016, p. 276-279).

Por sua vez, a requisição é subdividida em grupos: a) de documentos, certidões e informações; b) de instauração de procedimentos administrativos na órbita de outros órgãos; c) de divulgação de relatórios e de recomendações dirigidas ao Poder Público, aos prestadores de serviços públicos ou de relevância pública, asseguradores dos direitos constitucionais; d) de auxílio de força policial. Todos têm o objetivo de viabilizar o exercício da racionalidade persuasiva deliberativa e uma solução negociada, de maneira a suprir a falta de concretização dos direitos humanos ou a coibir atividade irregular ofensiva (SILVA, 2016, p. 280-284).

Também nas fases de iniciativa e de persuasão racional, existe a audiência extraprocessual, que é presidida pelo membro do MP com as características da oralidade, informalidade, simplicidade, negociação e resolutividade, com foco nos interesses e não nas posições. Ocorre igualmente nessas fases o inquérito civil (IC), que tem as seguintes características: titularidade exclusiva ministerial, formalidade restrita, instauração facultativa, natureza inquisitiva, publicidade mitigada e autoexecutoriedade instrutória. O inquérito pode chegar a três resultados: o arquivamento motivado, o acordo de concretização dos direitos humanos e o ajuizamento de ação

13 Destaquem-se as seguintes virtudes da fase de persuasão racional deliberativa: obediência pelos interlocutores à curiosidade respeitosa (capacidade de ouvir vários interlocutores com a preocupação de entender os argumentos lançados), acordo deliberativo (busca de uma decisão acordada coletiva), modéstia cognitiva (seguindo a lógica de preferência pela transformação), ambição cognitiva (disposição em se alcançar a melhor decisão possível), empatia (capacidade de imaginar problemas sob o ponto de vista do outro, ouvindo-se as questões antes e depois da decisão), responsividade (capacidade de dar respostas às escolhas objeto do acordo deliberativo firmado), clareza (simplicidade na expressão das razões consideradas na deliberação pactuada) e senso de falibilidade e provisoriedade (consciência de potencial revisibilidade, compatibilizando-se com a ideia de exigibilidade contínua, progressiva, gradual e dinâmica), visto que as rodadas procedimentais buscam alcançar acordos deliberativos (SILVA, 2016, p. 268-269). 
perante o Judiciário (SILVA, 2016, p. 284-296).

Nos mesmos termos, também como possível instrumento dialógico, existe a audiência pública, que possui fundamento na soberania popular direta. A audiência pública é um instrumento de diálogo com a sociedade, permitindo que o cidadão apresente propostas, reivindique direitos, elimine dúvidas, solicite providências, fiscalize a atuação de instituições de defesa social e exija a observância de deveres constitucionais e infraconstitucionais. De fato, na audiência pública, há elementos de participação, igualdade, racionalidade persuasiva e acordo fundamentado exigido pelo diálogo constitucional para alcançar a legitimidade procedimental e substancial (SILVA, 2016, p. 297-301).

Registre-se, ainda, o Acordo de Concretização de Direitos Humanos - um pacto que assume a defesa da ordem jurídica, dos direitos sociais e do regime democrático, obtendo resultados com maior brevidade e economicidade e sendo mais adequado à resolução dos conflitos de natureza coletiva que o processo judicial. Também como instrumento dialógico, o MP dispõe da recomendação, que pode exortar, instruir ou orientar pessoas físicas ou jurídicas, de direito público ou privado, para que sejam respeitados bens, direitos e interesses, fixando prazo para resposta obrigatória, mas desprovida de coercibilidade, imperatividade e autoexecutoriedade, com finalidade preventiva ou corretiva. Dentre as possíveis consequências que podem advir da resposta à recomendação, destacam-se as seguintes: a) o MP convence-se da inviabilidade da recomendação, a partir do raciocínio jurídico de que ela estava baseada em fatos superados ou desconhecidos; b) a causa é corrigida ou atendida; c) a causa é cancelada; d) o recomendado está convencido da legalidade do seu atuar (SILVA, 2016, p. 302-320) ${ }^{14}$.

A recomendação é um instrumento de viabilização do diálogo destinado à construção do consenso (ou melhor, do acordo) legítimo, a partir de um debate fundamentado entre o legitimado coletivo e o apontado como responsável pela lesão ou pela suposta ameaça a direito coletivo. $\mathrm{O}$ diálogo pode mostrar-se suficiente e adequado para a efetividade da tutela coletiva, diminuindo as judicializações e potencializando as oportunidades de formação de acordos (GAVRONSKI, 2010, p. 358 , p. 370 e p. 440$)$.

A propósito, após uma pesquisa sobre instrumentos de acesso à justiça e o cotejo de dados concretos, constatou-se a necessidade de priorizar as soluções consensuais negociadas (ou melhor, por acordo) dos conflitos, considerando as vantagens da celeridade e a natureza perene da pacificação dos conflitos (GAVRONSKI, 2010, p. 415).

Destacam-se aqui, dentre outros casos concretos, o dos servidores estaduais do Pará, o da Assembleia Legislativa do Estado do Pará (Alepa), o do lixão do Aurá e o de Cachoeira do Piriá, nos quais foi viabilizada a concretização de direitos sociais, especialmente pela utilização de instrumentos extraprocessuais. Nesses casos, observam-se a validade e a eficácia de decisões coletivas em regime de diálogo constitucional, para além da sua manutenção, inclusive, em todas as instâncias judiciais quando questionadas, viabilizando-se a exigibilidade e a exequibilidade na concretização de direitos fundamentais (SILVA, 2016, p. 192 e p. 263-264).

No caso dos servidores estaduais do Pará, foram estabelecidas rodadas procedimentais dialógicas entre Ministério Público do Trabalho (MPT), Estado do Pará, Judiciário Trabalhista e Ministério Público Federal (MPF), assegurando-se a concretização gradual, contínua, progresssiva e dinâmica do concurso público. Ainda, prestigiou-se a educação indígena, com a execução paulatina do acordo e o cumprimento das obrigações pactuadas conforme as dificuldades de concretização, além de novas rodadas procedimentais dialógicas em observância ao disposto no

14 Ressalta-se que, havendo termo de compromisso (ou melhor, Termo de Concretização de Direitos Humanos) perante um legitimado coletivo (ou recomendação atendida), caso constatada a identidade entre pedido e obrigação assumida no compromisso, faltará interesse de agir para eventual ação civil pública (ACP) proposta por outro legitimado coletivo (não se admitindo que o compromisso possa ser ignorado, exceto quando se tratar de transação indevida), embora alguns sustentem que o termo (ou a recomendação) consistiria em garantia mínima (GAVRONSKI, 2010, p. 404-407 e p. 411-413). 
artigo 6. ${ }^{\circ}$ da Convenção n. ${ }^{\circ} 169$ da Organização Internacional do Trabalho (OIT) (SILVA, 2016, p. $36-42)$.

Em relação ao caso concreto da Alepa, buscou-se a observância do princípio do concurso público, tendo sido expedida Recomendação e firmado Acordo de Concretização de Direitos Humanos (ACDH), os quais, respectivamente, cumpriram a Constituição, as leis e decisões judiciais (proferidas pela Justiça do Trabalho ${ }^{15}$ e pelo Supremo Tribunal Federal ${ }^{16}$ ). Ainda, referido ACDH resultou no distrato de todos os contratos temporários e no repasse de $\mathrm{R} \$ 2.000 .000,00$ (dois milhões de reais) à Secretaria de Trabalho, Emprego e Renda do Estado do Pará (Seter) para custear programas de capacitação de trabalhadores, entre outros (SILVA, 2016, p. 42-44).

Quanto ao lixão do Aurá (em Ananindeua, PA), após rodadas procedimentais entre Ministério Público do Trabalho, município de Ananindeua e Judiciário Trabalhista, em especial, em 7 de fevereiro de 2002, foi assinado um ACDH visando combater e erradicar o trabalho infantil, além de proteger o trabalho do adolescente e do jovem. Houve a apresentação de um projeto de lei para erradicar o trabalho infantil, com verbas orçamentárias correspondentes. Após novas rodadas procedimentais, em 9 de dezembro de 2009, suspendeu-se o processo de execução. O Município assumiu a obrigação de aparelhamento de um Conselho Tutelar e de um Centro de Referência de Assistência Social (CRAS), de construção de centros de formação profissional e de inclusão digital, bem como de abrigo para crianças e adolescentes, de aquisição de automóveis e de recolhimento de recursos ao Fundo para Infância e Adolescência (FIA), tudo para cumprimento até 2010. As obrigações municipais foram reforçadas em nova rodada procedimental em 21 de janeiro de 2014, verificando-se que a quase totalidade das cláusulas foi realizada voluntariamente (SILVA, 2016, p. 45-47).

Em relação a Cachoeira do Piriá (PA), também se buscou a erradicação do trabalho infantil e a proteção do trabalho do jovem e adolescente, tendo sido firmado um ACDH em 28 de janeiro de 2002. O Município assumiu várias obrigações, que, embora descumpridas, resultaram em execução com requerimento de expedição de precatório requisitório (que demonstra maior executividade e celeridade, porquanto superada a fase de conhecimento). Frisa-se que o MPT continua aberto à possibilidade de rodadas procedimentais por meio do diálogo constitucional (SILVA, 2016, p. 47-49).

Vale destacar a Resolução n. ${ }^{\circ} 118$ do Conselho Nacional do Ministério Público (CNMP), que dispõe sobre a Política Nacional de Incentivo à Autocomposição no âmbito do Ministério Público, a Recomendação n. ${ }^{\circ} 54$ do mesmo CNMP (fomentando a atuação autocompositiva e resolutiva do Ministério Público brasileiro) e o Manual de Negociação e Mediação para membros do Ministério Público ${ }^{17}$, visando aliviar a carga do Judiciário.

Nesse sentido, recomenda-se, como forma de efetivação e de promoção da justiça social, a atuação resolutiva (em detrimento da atuação demandista unilateral), pautada por uma concepção de justiça distributiva para atendimento dos direitos sociais com base em critérios objetivos, simultâneos, universais, iguais, de forma a evitar a distribuição predatória ou a "carona" de benefícios, rendas, ônus, responsabilidades, etc., assegurando-se o output de forma dialógica e concretizadora de direitos sociais (SILVA, 2016, p. 244-248).

De fato, observa-se que o diálogo tem elevado potencial para a concretização de direitos fundamentais; por isso, deve ser priorizado na solução de conflitos, problemas e insatisfações sociais a fim de viabilizar a construção de uma solução por acordo racional, conjunta, deliberativa e com o protagonismo dos envolvidos. Ao lado disso, vários são os instrumentos dialógicos de que

15 Processo n. ${ }^{\circ} 0001371-64.2010 .5 .08 .0013$.

16 Exarada na ADI-PA n. ${ }^{\circ} 2687-9$.

17 Elaborado em parceria pelo CNMP e pela Escola Nacional de Mediação, vinculada ao Ministério da Justiça. Disponível em: <https://www.cnmp.mp.br/portal/publicacoes/245-cartilhas-e-manuais/7560-contribuicoes-paraatuacao-do-ministerio-publico-na-copa-das-confederacoes-e-na-copa-do-mundo-2>. Acesso em: 5 nov. 2019. 
dispõe na atualidade o Ministério Público. Assim, uma eventual atuação coletiva que não priorize o diálogo pode revelar-se como falta de interesse processual e violação à secundariedade da jurisdição.

\section{A PREMISSA dialógICA PRÉ-PROCESSUAL NAS AÇÕeS COLETIVAS E A AUSÊNCIA DE INTERESSE NA JUDICIALIZAÇÃO: CASOS CONCRETOS NO ESTADO DO PARÁ}

Consoante demonstrado anteriormente, o diálogo apresenta-se como caminho importante na busca de solução por meio de um acordo racional, deliberativo e plural, com o protagonismo dos envolvidos. O Ministério Público dispõe na atualidade de vários instrumentos dialógicos para viabilizar esse diálogo.

Nesse sentido, vale destacar alguns casos concretos recentes ocorridos no Estado do Pará: a) o caso de desmatamento, com apoio recíproco entre o Estado do Pará e o Instituto Brasileiro do Meio Ambiente e dos Recursos Naturais Renováveis (Ibama) para a proteção ambiental em vários municípios desse Estado, envolvendo a atuação do Ministério Público Federal em Belém (PA); b) o caso do saneamento básico e de políticas públicas conexas de asfaltamento e limpeza de canais ligados à Avenida João Paulo II, em Belém (PA), com a atuação da Promotoria de Belém; c) a questão das obras do BRT e correspondentes medidas a serem adotadas para viabilizar o trânsito e evitar acidentes no seu trajeto, envolvendo a atuação da Promotoria de Ananindeua (PA).

Como primeiro exemplo, o Ministério Público Federal no Estado do Pará ajuizou uma ação civil pública contra o desmatamento no Estado, alegando negativa de apoio ao Ibama por parte da Polícia Militar (PM) ${ }^{18}$. Segundo o MPF, seria indevido condicionar o apoio da PM ao Ibama ao Termo de Cooperação respectivo, tendo em vista a responsabilidade ambiental solidária; por isso, solicitou liminarmente o fornecimento de apoio ostensivo da PM ao Ibama quando da deflagração de suas fiscalizações periódicas, independentemente do Termo de Cooperação Técnica.

Em resposta, o Estado do Pará destacou, entre outros, a importância da adequada e efetiva tutela do direito fundamental relacionado ao meio ambiente por meio de ação planejada (conforme o disposto no artigo $4 .^{\circ}$ da LC n. $\left.{ }^{\circ} 140 / 2011\right)$. Apontou a ausência de interesse em demanda de alta complexidade, envolvendo questão estrutural de política pública, a recomendar atuação prudente e efetiva para lograr eficiência na exata medida e nos limites do necessário ${ }^{19}$. Sustentou igualmente a possibilidade de expedir recomendação ministerial ao Ibama para que firmasse o Termo de Cooperação ${ }^{20}$ e colocou-se à disposição do MPF, demonstrando a abertura ao diálogo, respeitadas as competências constitucionais e legais.

18 Processo Conselho Nacional de Justiça (CNJ) n. ${ }^{\circ}$ 1006175-98.2019.401.3900, 9. ${ }^{a}$ Vara Federal da Seção Judiciária do Estado do Pará, ajuizado em 10 de outubro de 2019, apontando falta de apoio no período de junho a agosto de 2019. 19 Também foram encaminhados documentos sobre o apoio disponibilizado pela PM/PA ao Ibama e esclareceu-se que as solicitações da autarquia federal foram atendidas em prazo hábil (ainda que inexistente o Termo de Cooperação respectivo) e que houve um corte no repasse federal ao Ministério do Meio Ambiente (MMA). Registrou-se notícia de um corte de $\mathrm{R} \$ 187$ milhões do MMA, com um corte de $95 \%$ do orçamento previsto para a agenda climática e o

bloqueio de $38,4 \%$ da prevenção e do controle de incêndios. Disponível em: <https://www.oeco.org.br/noticias/governo-corta-r-187-milhoes-do-mma-saiba-como-o-corte-foi-dividido/>. Acesso em: 16 out. 2019. Ainda, registrou-se a recusa federal em receber auxílio externo e a manifestação expressa do Estado do Pará em sentido diverso (leia-se: o Estado do Pará está disposto a receber auxílio externo). Disponível em: <https://noticias.uol.com.br/meio-ambiente/ultimas-noticias/redacao/2019/08/27/helder-barbalho-reuniaogovernadores-com-bolsonaro.htm>. Acesso em: 16 out 2019.

20 No sentido de que fosse firmado o Termo de Cooperação respectivo e de que fossem estabelecidas rodadas procedimentais para viabilizar uma maior efetividade na tutela ambiental por meio de ação planejada e conjunta, de maneira dialógica, por acordo extraprocessual, tendo em vista a preservação do Pacto Federativo e dos princípios da legalidade e da eficiência. Ainda, o Estado já havia disponibilizado apoio às ações de fiscalização conjunta, associado à contínua atuação do Estado nas suas funções institucionais, buscando tutelar adequada e efetivamente o meio ambiente. 
Contudo, não se concretizou a iniciativa ministerial de dialogar com o Ibama para que informasse sobre a viabilidade (ou não) de realizar o Termo de Cooperação Técnica. O MPF não deu continuidade ao diálogo extraprocessual como mecanismo possivelmente apto e efetivo para a tutela do meio ambiente. Assim, o Órgão Ministerial optou pela judicialização como único meio apto e necessário para a adequada solução do conflito naquele momento.

Consoante destacado anteriormente, a recomendação consiste em um dos instrumentos dialógicos de que dispõe o MP para a solução de conflitos por acordo (SILVA, 2016). O Estado sustentou a desnecessidade de judicialização, uma vez que ainda não havia sido tentada a iniciativa do diálogo com o Ibama para a análise de possível solução por acordo, racional, deliberativo e plural, com o protagonismo dos envolvidos.

O fato de o MPF concentrar-se na jurisdição, quando ainda não se revelava necessária e proporcional, assoberbando ainda mais o Judiciário, pode ter configurado vício processual de interesse-necessidade da medida judicial proposta na tutela efetiva do meio ambiente, inclusive porque há casos em que a jurisdição não é o único meio nem o mais útil para a solução de controvérsias e o acesso à justiça (GAVRONSKI, 2010, p. 235; SALLES, 2006, p. 781-783).

Posteriormente, o Ibama enviou a minuta de um Acordo de Cooperação Técnica (ACT) para assinatura com o Estado do Pará $^{21}$ e, em seguida, o MPF peticionou a desistência da ação judicial $^{22}$.

Assim, a iniciativa ministerial de propor ao Ibama qualquer medida dialógica prévia teria possivelmente configurado uma forma de efetiva tutela do direito fundamental ao meio ambiente sadio e ecologicamente equilibrado. Esse instrumento dialógico, que é disponibilizado ao Parquet, entre tantos outros, permite alcançar o resultado com maior celeridade, redução de custos e de demandas judiciais desnecessárias, que assoberbam indevidamente o Judiciário, na medida em que poderiam ser evitadas e solucionadas por outros mecanismos que garantam a ordem jurídica justa e concretizem os direitos fundamentais.

Noutro caso concreto, agora em ACP ajuizada pelo Ministério Público do Estado do Pará ${ }^{23}$ alegando deficiência dos instrumentos de mobilidade urbana em Belém (PA), exigiram-se saneamento básico, saúde local e pavimentação asfáltica. Solicitou liminar para determinar que o Estado do Pará promovesse a limpeza mecânica e a drenagem de canais, assim como a pavimentação de algumas passagens transversais, sob pena de aplicação de multa diária.

21 Demonstrando que a assinatura do referido ACT era necessária e viável. Foi injustificadamente inviabilizada anteriormente, seja pelo Ibama, que não se dispôs a realizá-lo ainda que tivesse interesse fático e houvesse previsão legal, seja pelo MPF, que não comprovou a iniciativa do diálogo com o Ibama para que pudesse esclarecer a viabilidade - ou justificasse a negativa - do ACT. O Estado disponibilizou ao Ibama em 29 de maio de 2019 e em 25 de junho de 2019 o setor de Centro de Contratos e Convênios para a celebração do Termo respectivo. O MPF judicializou a demanda em 10 de outubro de 2019, após resposta da Secretaria de Segurança Pública em 24 de setembro de 2019 à Recomendação Ministerial de 2 de setembro de 2019. Não foi expedida qualquer medida ministerial ao Ibama para assinatura de acordo de cooperação técnica ou justificativa sobre eventual impossibilidade. Em despacho de 24 de outubro de 2019, o juízo manifestou-se pela oitiva prévia dos demandados. O Ibama protocolou manifestação preliminar em 4 de novembro de 2019, acostando um e-mail de 25 de outubro de 2019 com a minuta do Termo de Cooperação dirigida ao Estado.

22 O pedido de desistência ministerial foi protocolado por "superveniente ausência de interesse processual", dando conhecimento da disponibilização do efetivo policial militar no período de " 01 de janeiro a 30 de setembro de 2019", além da assinatura do termo de cooperação. Registre-se que a ação foi protocolada em 10 de outubro de 2019, portanto, em período posterior àquele informado na petição do MPF (de 1. ${ }^{\circ}$ de janeiro a 30 de setembro de 2019). Referido pedido de desistência ministerial foi homologado judicialmente em 26 de maio de 2020. Disponível em: <https://pje1g.trf1.jus.br/consultapublica/ConsultaPublica/DetalheProcessoConsultaPublica/listView.seam?ca=cb395 6924bf788ba0bea245a7e5fca1c99009654a1964999>. Acesso em: 28 maio 2020.

23 Processo CNJ n. ${ }^{\circ}$ 0854727-15.2019.8.14.0301, 5. ${ }^{a}$ Vara da Fazenda Pública e Tutelas Coletivas de Belém (PA), protocolado pela $1 .^{\text {a }}$ Promotoria de Justiça do Meio Ambiente, Patrimônio Cultural, Habitação e Urbanismo (1. ${ }^{a}$ $\mathrm{PJ} / \mathrm{MA} / \mathrm{PC} / \mathrm{HU})$. 
Em manifestação preliminar, o Estado esclareceu as atribuições do município de Belém ${ }^{24}$ e a consequente ilegitimidade passiva estadual, inclusive considerando a omissão in concreto do Município. Narrou que a complexidade da demanda exigia a atuação de vários atores públicos para a implementação da política pública então solicitada (tais como o município de Belém, a Companhia de Habitação e as Centrais Elétricas do Pará) e informou-se a duplicidade de apuração no âmbito do Ministério Público estadual (ora demandista, ora dialógica) ${ }^{25}$.

A liminar foi deferida, e, após recurso do Estado, o TJPA entendeu que o município de Belém também deveria ter sido demandado ${ }^{26}$.

Diante disso, é importante frisar a atuação dialógica e proporcional ${ }^{27}$ (diferente da atuação demandista acima indicada no processo judicial ${ }^{28}$ ), priorizando a solução dialógica de questão complexa e interinstitucional, como mecanismo de maior efetividade, proporcionalidade e eficiência, prestigiando a Resolução n. ${ }^{\circ} 118$ do CNMP, a Recomendação n. ${ }^{\circ} 54$ do CNMP e o Manual de Negociação e Mediação para membros do Ministério Público ${ }^{29}$, afastando a judicialização prematura e desnecessária a sobrecarregar ainda mais o Judiciário.

Frise-se que no Inquérito Civil que resultou em recomendação ministerial houve a possibilidade de estabelecimento do diálogo como premissa de solução de conflitos. Cabe salientar que o diálogo é recomendável em especial nos conflitos marcados pela complexidade, em razão dos diversos atores sociais envolvidos; sua participação plural e deliberativa confere maior efetividade à concretização de direitos fundamentais ${ }^{30}$, minimizando gradualmente a postura demandista precipitada, que afasta os instrumentos dialógicos disponíveis, entre os quais a

24 Conforme artigo 23, IV e IX, e artigo 30, V, da CRFB, artigo 9. ${ }^{\circ}$ da LC n. ${ }^{\circ}$ 140/2011, Lei n. ${ }^{\circ} 11.445 / 2007$, Lei n. ${ }^{\circ}$ 9.113/2015 e Decreto Municipal n. ${ }^{\circ} 86.545 / 2016$.

25 Quanto à duplicidade de apuração e diversidade de atuação ministerial, tramitaram no MP o Inquérito Civil n. ${ }^{\circ}$ 000168-113/2013-MP, 1. ${ }^{\mathrm{a}} \mathrm{PJ} / \mathrm{MA} / \mathrm{PC} / \mathrm{HU}$ (que deu ensejo à ação judicial) e o Inquérito Civil n. ${ }^{\circ} 000612-125 / 2016,2 .{ }^{\mathrm{a}}$ $\mathrm{PJ} / \mathrm{MA} / \mathrm{PC} / \mathrm{HU}$, no qual foi priorizada a solução dialógica, consensual e proporcional pelo Parquet, nessa questão estrutural e complexa e que resultou em "Recomendação à Câmara Municipal de Belém e à Secretaria Municipal de Planejamento - SEGEP para a inclusão de recursos para as obras do Canal do Mártir e Ana Deusa, bem como obras de urbanização no bairro Curió-Utinga, no orçamento do ano de 2020".

26 Conforme decisão no Agravo de Instrumento n. ${ }^{\circ}$ 0803130-03.2020.8.14.0000 em tramitação no TJPA.

27 Pela $2^{\mathrm{a}}$ Promotoria no Inquérito Civil Público n. ${ }^{\circ} 000612-125 / 2016$.

28 No Inquérito Civil Público n. ${ }^{\circ}$ 000168-113/2013-MP, 1 a $^{\text {a }}$ Promotoria de Justiça, que resultou no ajuizamento da ACP n. ${ }^{\circ}$ 0854727-15.2019.8.14.0301. Aliás, o Inquérito Civil da 1. ${ }^{a}$ Promotoria de Justiça começou a tramitar em 3 de março de 2005, tendo sido convertido em Inquérito Civil Público (ICP) somente em 2013, no qual foi diligenciada Vistoria Técnica em 22 de janeiro de 2014. O IC foi ajuizado em outubro de 2019, após 14 (quatorze) anos contados do início da apuração e 6 (seis) anos após sua conversão em ICP. Mais: sem demonstrar as tentativas de solução dialógica (especialmente, sem expedir qualquer Recomendação a qualquer dos atores envolvidos) e sem inserir o município de Belém nas tratativas dialógicas extraprocessuais ou na demanda judicial.

29 Disponível em: <https://www.cnmp.mp.br/portal/publicacoes/245-cartilhas-e-manuais/7560-contribuicoes-paraatuacao-do-ministerio-publico-na-copa-das-confederacoes-e-na-copa-do-mundo-2>. Acesso em: 18 jun. 2020.

30 É oportuno frisar os casos indicados anteriormente, dos servidores estaduais do Pará, da Alepa, de Cachoeira do Piriá e do lixão do Aurá, que resultaram no efetivo cumprimento contínuo, gradual, progressivo e dinâmico, observadas as dificuldades devidamente justificadas e submetidas às rodadas procedimentais dialógicas constitucionais (SILVA, 2016, p. 36-49). Cabe igualmente lembrar o caso da Vila Chocolatão: Ação Reivindicatória n. ${ }^{\circ}$ 2000.71.00.000973-1, da Vara Federal Ambiental de Porto Alegre, promovida pela União Federal, que se dizia proprietária de uma área em que seria construído o Centro Administrativo Federal de Porto Alegre, mas era utilizada como lixão no município de Porto Alegre e ocupada por aproximadamente duas centenas de famílias. Nesse caso, a partir de rodadas procedimentais promovidas entre Ministério Público Federal, União Federal, município de Porto Alegre, Departamento Municipal de Habitação (DMHAB), Departamento Municipal de Limpeza Urbana (DMLU), Associação dos Moradores da Vila Chocolatão e Associação de Catadores e Recicladores da Vila Chocolatão, foram assegurados direitos sociais, como o direito à moradia - por meio de contrato de concessão de direito real de uso -, o direito à educação - por meio de construção de unidade de educação infantil -, o direito à saúde - por meio da remoção dos moradores, com o apoio da Unidade Básica próxima ao assentamento -, o direito ao trabalho - com a organização da coleta seletiva e a capacitação dos associados -, além do direito ao lazer - mediante previsão de construção de praça e quadra poliesportiva (SILVA, 2016, p. 50-51).

Revista de Direito Brasileira | Florianópolis, SC | v. 27 | n. 10 | p.281-299 | Set./Dez. 2020 
recomendação ${ }^{31}$.

Noutro caso concreto de atuação ministerial estadual, foi ajuizada uma $\mathrm{ACP}^{32}$ alegando precariedade de sinalização e de iluminação de via. A construtora responsável pela obra teria retirado parte da iluminação pública existente sem a adoção das medidas mitigadoras correspondentes. Além disso, teria havido modificação e falha de sinalização pelo Departamento de Trânsito (Detran) estadual, causando acidentes e óbitos. Sustentava-se a necessidade de iluminação provisória nos postes laterais e de pintura de faixas de pedestres, com a presença de agentes de trânsito para auxiliar na travessia e de viaturas no perímetro.

O MP afirmou que era "totalmente desnecessária a realização de audiência de justificação" e pleiteou liminarmente, entre outros, o embargo ou a paralisação das obras.

O Juízo designou audiência de tentativa de conciliação ${ }^{33}$, e, após os respectivos esclarecimentos e diálogo entre os envolvidos ${ }^{34}$, deliberou-se pela suspensão do prazo de contestação e foi concedido prazo para juntada de novos documentos quanto às medidas adotadas. Em seguida, a liminar foi indeferida sob o fundamento de que o MP não comprovou as suas alegações.

Nesse contexto, observa-se que o diálogo foi priorizado pelo Estado, que usou de suas atribuições constitucionais e legais, esclarecendo tempestivamente a complexidade da demanda e das medidas adotadas para alcance de uma decisão de mérito justa.

O diálogo foi proporcionado pela designação de audiência de tentativa de conciliação pelo Juízo, a despeito da afirmação expressa da inicial no sentido de afastá-lo.

A postura de inviabilização do diálogo não tem o potencial de concretizar e realizar os

31 Observa-se que o ICP da 2. ${ }^{a} \mathrm{PJ} / \mathrm{MA} / \mathrm{PC} / \mathrm{HU}$ é posterior (2016) ao da 1. ${ }^{\mathrm{a}} \mathrm{PJ} / \mathrm{MA} / \mathrm{PC} / \mathrm{HU}$ (2013). Contudo, a 2. ${ }^{\mathrm{a}}$ Promotoria atuou em momento anterior à $1 .{ }^{\text {a }}$ Promotoria, com a expedição de recomendação à Câmara Municipal de Belém e à Secretaria Municipal de Planejamento (Segep), sendo adotada a medida dialógica da recomendação anteriormente ao ajuizamento da ação pela $1 .{ }^{a}$ Promotoria. Leia-se: a $2{ }^{\mathrm{a}}$ Promotoria analisou com maior urgência, ampliando o diálogo plurideliberativo e racional, enquanto a atuação demandista da 1 . $^{\text {a }}$ Promotoria foi revista pelo TJPA, que por sua vez incluiu o município de Belém (PA) no polo passivo da demanda.

32 Ação Civil Pública n. ${ }^{\circ}$ 0809123-43.2019.814.0006, ajuizada em 8 de agosto de 2019 na Vara da Fazenda Pública

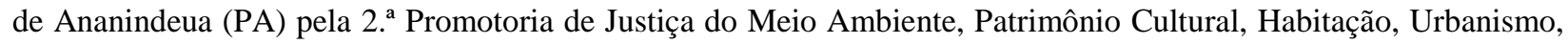
Consumidor e Fundações de Ananindeua (PA).

33 Registre-se que, ao designar a audiência, o juízo fundamentou-se na premissa de que a "paralisação de obra de grande porte deve ser vista com a máxima cautela e de forma excepcional, impondo-se a tentativa de solução conciliada".

$34 \mathrm{Na}$ referida audiência, durante o diálogo entre os envolvidos, a área técnica demonstrou todas as medidas adotadas pelo Poder Público, bem como os riscos de um embargo ou de uma paralisação da obra, que possivelmente interferiria em empréstimo internacional e ensejaria maior número de acidentes e óbitos (objeto que o MP justamente objetivava tutelar). Ainda, com base em dados concretos, comprovou-se a diminuição (e não o aumento) do número de acidentes e óbitos após o início da realização das obras. Atestou-se ainda que a medida solicitada pelo MP (pintura de faixas de pedestres para os transeuntes) não era a mais segura (como o seria a instalação de semáforos). Informou-se, além disso, que a iluminação dos postes laterais (como requerido na inicial) teria o potencial de aumentar os acidentes, recomendando-se a iluminação adequada, como devidamente informado ao Juízo, acostando-se documentos comprobatórios. Ao lado disso, os envolvidos questionaram a postura de afastamento dialógico do MP, tendo em vista a disponibilidade para a solução autocompositiva e as informações preliminares apresentadas pelo Estado. Como justificativa comprobatória, foram acostados os ofícios que solicitaram informações aos órgãos técnicos; embora pendentes de resposta naquele momento, foram protocolados pelo Estado no MP no dia seguinte, tendo sido encaminhados o Projeto e as informações prestadas pelo Detran/PA em atendimento à Recomendação. Mais ainda: questionou-se a afirmação expressa na exordial no sentido de entender desnecessária a realização de audiência de justificação e ainda a confirmação no capítulo destinado aos pedidos de desinteresse na audiência de conciliação. O questionamento deveu-se em especial à complexidade e à importância dessa questão de política pública, mas também à previsão legal expressa no artigo $2 .^{\circ}$ da Lei n. ${ }^{\circ} 8.437 / 1992$, no artigo 334 do $\mathrm{CPC}$, bem como na Resolução n. ${ }^{\circ} 118$ do CNMP e na Recomendação n. ${ }^{\circ} 54$ do CNMP. Também se questionou a ausência do município de Ananindeua no polo passivo, visto que se discutia a iluminação pública, serviço de responsabilidade do município, com a respectiva fonte de custeio prevista no artigo 149-A da CRFB, bem como a ausência da construtora, que, segundo a exordial, teria retirado a iluminação pública, cuja recolocação era então pleiteada.

Revista de Direito Brasileira | Florianópolis, SC | v. 27 | n. 10 | p.281-299 | Set./Dez. 2020 
direitos fundamentais. No caso em questão, havia um pedido liminar de paralisação ou de embargo da obra que não resolveria a questão do tráfego, nem garantiria a proteção das vidas, da segurança e da saúde da população envolvida. Observam-se uma possível falta de interesse e a ofensa à secundariedade da jurisdição na tutela dos direitos fundamentais difusos então objeto da demanda. Frise-se que o MP não priorizou a oitiva da parte adversa para tentar uma solução dialógica racional, plural e deliberativa, que era possível - visto que o Estado não inviabilizou o diálogo, atendendo às solicitações tempestivamente - e recomendável - considerando a intensa complexidade da questão debatida.

Não consistindo a jurisdição na única forma de solução dos conflitos, vale destacar que não é recomendável afastar o diálogo, inclusive nos casos em que ocorrer a judicialização indevida. De fato, é fundamental a pluralização da informação com o objetivo de qualificar a decisão, fornecendo-se maiores subsídios para garantir a legitimidade substantiva da decisão.

Cabe lembrar que, antes mesmo da edição do atual CPC, já havia lição doutrinária ressaltando a materialização do devido processo constitucional e a necessidade do papel dialógico do juiz com as partes e demais sujeitos processuais. $\mathrm{O}$ dever de prevenção e de consulta deveria nortear a prática cooperativa com as partes, o que permitiria alcançar um resultado positivo para os litigantes e para a sociedade (GÓES, 2012, p. 109-111).

A análise do princípio cooperativo (diálogo processual ou responsabilidade judicial ${ }^{35}$ ) também é feita por quem entende o contraditório como obrigação de debate e de diálogo judiciário. Nessa concepção, os deveres cooperativos são os seguintes: a) dever de esclarecimento, que representa o dever do juiz de esclarecer aos demandantes as dúvidas que tenham sobre as alegações, os pedidos ou a posição em juízo; b) dever de prevenção, que envolve o dever de avisar acerca do perigo de o êxito dos pedidos ser frustrado pela utilização inadequada do processo; c) dever de consulta, que consiste no dever que o juiz tem de consultar os demandantes antes de decidir sobre qualquer questão, para permitir-lhes que exerçam influência na convicção a ser formada; d) dever de auxílio, que consiste no dever que o juiz tem de ajudar os demandantes na superação de eventuais dificuldades que impeçam o exercício de direitos, faculdades, cumprimento de ônus e deveres processuais (MITIDIERO, 2011, p. 84-86).

Dessa forma, observa-se que a premissa dialógica autocompositiva ou processual é importante mecanismo para alcançar a ordem jurídica justa. Ao lado disso, o MP possui instrumentos para viabilizar o diálogo, como a recomendação.

Assim, eventual postura ministerial que afaste referida premissa do diálogo e priorize a litigância implica atuação processual carente de interesse-necessidade, especialmente quando não se utiliza previamente o instrumento dialógico da recomendação.

Nesse contexto, os direitos que o MP pretendia tutelar podem ser indevidamente questionados na via judicial, o que importaria em prematura litigiosidade excessiva e potenciais prejuízos ao direito material que a litigância provoca, seja a inviabilização do Judiciário, seja a impossibilidade de os protagonistas do conflito deliberarem racionalmente de maneira autônoma e plural sobre a solução dos problemas por acordo, em especial, nos casos de políticas públicas que apresentam acentuada conflituosidade e intensa complexidade, como a tutela ambiental envolvendo desmatamento no Estado, saneamento básico e complexas obras públicas referentes a trânsito e a transporte.

35 A esse respeito, a garantia do contraditório com a efetiva consideração dos argumentos dos interessados (no convencimento referente à responsabilidade pública), bem como a ação comunicativa dialógica (na via autocompositiva plurideliberativa) minimizam os riscos de erro e maximizam as chances de acerto. Buscam-se assim melhores razões públicas e viabiliza-se a legitimação democrática procedimental, com a participação efetiva dos sujeitos envolvidos, e a legitimação decisória, com a prestação dos esclarecimentos e argumentos que permitam a adequada exigibilidade e exequibilidade referente ao conteúdo do resultado alcançado com a decisão final. 


\section{CONCLUSÃO}

Demonstrada a importância do acesso à justiça e da premissa dialógica como um importante caminho para a resolução de conflitos de maneira a concretizar os direitos fundamentais, questionou-se a possível ausência de interesse processual e a falta de atendimento da secundariedade da jurisdição na tutela dos direitos coletivos, quando eventualmente é afastada a premissa dialógica autocompositiva na tutela dos direitos fundamentais.

Buscou-se demonstrar a viabilidade e a possível solução de conflitos de maneira plural, deliberativa, racional e com o fortalecimento do protagonismo dos reais envolvidos, individuais e coletivos. Tais características objetivam potencializar a solução por acordo desses conflitos, assegurando a concretização e a realização dos direitos fundamentais com menores custos e maior celeridade.

A pluralização de intérpretes constitucionais e o procedimento dialógico, com a participação dos envolvidos na concretização dos direitos fundamentais, têm o potencial de suscitar o enriquecimento epistemológico por meio de argumentos diversos e de maior comprometimento, assegurando não só a exigibilidade, mas também a exequibilidade, com o efetivo cumprimento pelos envolvidos.

O diálogo sob uma perspetiva deliberativa permite o exercício da razão pública e da civilidade com a viabilização de ampla participação e fundamentação. A interação deliberativa minimiza os riscos de erro e maximiza as chances do acerto, buscando razões públicas. Nesse contexto, vários são os instrumentos dialógicos de que dispõe o Ministério Público, entre os quais a notificação, a audiência pública e a recomendação.

Considerando os potenciais benefícios inerentes ao diálogo (a qualificação da decisão e a conformação de interesses diversos, com maior concretização dos direitos fundamentais) e os vários instrumentos dialógicos disponibilizados ao Ministério Público, uma eventual postura demandista que não priorize a autocomposição dialógica pode configurar-se desnecessária e carente de interesse, principalmente quando versar sobre direitos fundamentais, não se afastando um possível controle judicial.

A esse respeito, destaque-se a complexidade de processos estruturais, como políticas públicas relativas à tutela do meio ambiente, do saneamento básico e de complexas obras estruturantes de trânsito e de transporte. Nesse caso, uma eventual postura de legitimado coletivo que afaste a premissa dialógica pode representar postura procedimental desnecessária e carente de interesse para a concretização e a realização dos direitos fundamentais. Consequentemente, tal postura demandista pode consistir em um vício na atuação coletiva, passível de controle judicial em razão da falta de interesse.

Nesses termos, considerando os diversos mecanismos extraprocessuais dialógicos disponibilizados ao Ministério Público, uma eventual judicialização precipitada que afaste o diálogo para a solução de questões estruturantes pode ser, igualmente, objeto de controle judicial por ausência de interesse-necessidade (conforme RE 631240, precedente formalmente vinculante ${ }^{36}$ ). É o que se extrai dos casos concretos ilustrativos acima analisados, envolvendo o

$36 \mathrm{O}$ RE n. ${ }^{\circ} 631.240$ concluiu pela necessidade de requerimento prévio para comprovar a presença de interesse de ir a juízo. A esse respeito, considerando a previsão do artigo 102, § 3..$^{\circ}$ da CRFB/88 e do artigo 927, III, do CPC, o recurso extraordinário possui força formalmente vinculante. Caso não fosse formalmente vinculante, também seria defensável a sua força materialmente vinculante, visto que tem sido seguido pelos Tribunais pátrios (MAGALHÃES; SILVA, 2012, p. 93-94), conforme os seguintes julgados, entre outros: STJ. AgRg no REsp 936.574/SP. Relator: Min. Paulo de Tarso Sanseverino. Julgamento: 02/08/2011. Publicação: DJe 08/08/2011; STJ. REsp 1.383.566/RS. Relator: Min. Herman Benjamin. Publicação: 23/08/2013; STJ. AgRg no REsp 1.399.337/SC. Relator: Min. Herman Benjamin. Publicação: 07/11/2014. No mesmo sentido, o TJPA nos seguintes julgados: TJPA (1. Turma de Direito Privado). 2019.01434755-23, não informado. Relator: Constantino Augusto Guerreiro. Julgamento: 16/04/2019. Publicação: 16/04/2019; TJPA (1. Câmara Cível Isolada). 2016.04776818-95, não informado. Relator: Leonardo de Noronha 
Estado do Pará. Por isso, defende-se a priorização da postura dialógica racional pelos representantes coletivos na concretização e na realização dos direitos fundamentais como medida de acesso à ordem jurídica justa.

\section{REFERÊNCIAS}

ABRAMOVICH, Víctor. Linhas de trabalho em direitos econômicos, sociais e culturais: instrumentos e aliados. SUR: Revista Internacional de Direitos Humanos, São Paulo, v. 2, n. 2, p. 188-223, 2005.

ALEXY, Robert. Teoria dos direitos fundamentais. São Paulo: Malheiros: 2008.

CALAMANDREI, Piero. Estudios sobre el proceso civil. Tradução de Santiago Sentis Melendo. Buenos Aires: Editorial Bibliografica, 1945.

CÂMARA, Alexandre Freitas. Lições de direito processual civil. 24. ed. São Paulo: Atlas, 2013. v. 1 .

CÂMARA, Alexandre Freitas. O novo processo civil brasileiro. 4. ed. rev. e atual. São Paulo: Atlas, 2018.

CINTRA, Antônio Carlos de Araújo; GRINOVER, Ada Pellegrini; DINAMARCO, Cândido Rangel. Teoria geral do processo. 21. ed. rev. e atual. São Paulo: Malheiros, 2005.

CRESPO, Mariana Hernandez. Diálogo entre os professores Frank Sander e Mariana Hernandez Crespo: explorando a evolução do Tribunal Multiportas. In: ALMEIDA, Rafael Alves de; ALMEIDA, Tania; CRESPO, Mariana Hernandez (Org.). Tribunal multiportas: investindo no capital social para maximizar o sistema de solução de conflitos no Brasil. Rio de Janeiro: Editora FGV, 2012. p. 25-37.

FISS, Owen. Modelos de adjudicação. Cadernos Direito GV, São Paulo, v. 1, n. 8, p. 3-57, nov. 2005.

GAVRONSKI, Alexandre Amaral. Técnicas extraprocessuais de tutela coletiva: a efetividade da tutela coletiva fora do processo judicial. São Paulo: Revista dos Tribunais, 2010.

GÓES, Gisele Santos Fernandes. Processo civil cooperativo. A Leitura: Caderno da Escola Superior da Magistratura do Estado do Pará, Belém, v. 5, p. 5-179, 2012.

KAUFMANN, Arthur; HASSEMER, Winfried (Org.). Introdução à filosofia do direito e à teoria do direito contemporâneas. Tradução de Marcos Keel. Lisboa: Fundação Calouste Gulbenkian, 2008.

LANGFORD, Malcolm. Judicialização dos direitos econômicos, sociais e culturais no âmbito nacional: uma análise sócio-jurídica. SUR: Revista Internacional de Direitos Humanos, São Paulo, v. 6, n. 11, p. 99-133, dez. 2009. 
MACEDO, Elaine Harzheim; RODRIGUES, Ricardo Schneider. Negócios jurídicos processuais e políticas públicas: tentativas de superação das críticas ao controle judicial. Revista de Processo, São Paulo, v. 42, n. 273, p. 69-93, nov. 2017.

MAGALHÃES, Breno Baía; SILVA, Sandoval Alves da. O grau de vinculação dos precedentes à luz do STF: o efeito vinculante é absoluto? Revista de Informação Legislativa, Brasília, DF, v. 49, n. 195, p. 77-95, jul./set. 2012. Disponível em:

<https://www2.senado.leg.br/bdsf/bitstream/handle/id/496599/000966849.pdf>. Acesso em: 17 mar. 2020.

MITIDIERO, Daniel Francisco. Colaboração no processo civil: pressupostos sociais, lógicos e éticos. 2. ed. São Paulo: Revista dos Tribunais, 2011 (Coleção Temas Atuais de Direito Processual Civil, v. 14).

NOGUEIRA, Gustavo Santana; NOGUEIRA, Suzane de Almeida Pimentel. O sistema de múltiplas portas e o acesso à justiça no Brasil: perspectivas a partir do novo Código de Processo Civil. Revista de Processo, São Paulo, v. 43, n. 276, p. 505-522, fev. 2018.

OSNA, Gustavo. Processo civil, cultura e proporcionalidade: análise crítica da teoria processual. São Paulo: Revista dos Tribunais, 2017.

RAY, Larry; CLARE, Anne L. The multi-door Courthouse idea: building the Courthouse of the future... today. Ohio State Journal on Dispute Resolution, Ohio, v. 1, n. 1, p. 7-54, 1985.

RODRIGUES, Marcelo Abelha. Fundamentos da tutela coletiva. Brasília, DF: Gazeta Jurídica, 2017.

RODRÍGUEZ-GARAVITO, César. Beyond the Courtroom: the impact of judicial activism on socioeconomic rights in Latin America. Texas Law Review, [s.1.], v. 89, n. 7, p. 1669-1698, 2011.

SALLES, Carlos Alberto de. Mecanismos alternativos de solução de controvérsias e acesso à justiça: a inafastabilidade da tutela jurisdicional recolocada. In: FUX, Luiz; NERY JR., Nelson; WAMBIER, Teresa Arruda Alvim (Coord.). Processo e Constituição: estudos em homenagem ao Professor José Carlos Barbosa Moreira. São Paulo: Revista dos Tribunais, 2006. p. 779-792.

SALLES, Carlos Alberto de (Org.). Processo civil e interesse público: o processo como instrumento de defesa social. São Paulo: Revista dos Tribunais, 2003.

SARMENTO, Daniel. Dignidade da pessoa humana: conteúdo, trajetórias e metodologia. Belo Horizonte: Fórum, 2016.

SILVA, Sandoval Alves da. Direitos sociais: leis orçamentárias como instrumento de implementação. Curitiba: Juruá, 2007.

SILVA, Sandoval Alves da. O (in)acesso à justiça social com a demolidora reforma trabalhista. In: MIESSA, Élisson; CORREIA, Henrique (Org.). A reforma trabalhista e seus impactos. Salvador: Juspodivm, 2017. v. 1, p. 1075-1103. 
SILVA, Sandoval Alves da. O Ministério Público e a concretização dos direitos humanos. Salvador: Juspodivm, 2016.

TARTUCE, Fernanda. Mediação nos conflitos civis. Rio de Janeiro: Forense; São Paulo: Método, 2019.

THEODORO JÚNIOR, Humberto. Curso de direito processual civil: teoria geral do direito processual civil, processo de conhecimento e procedimento comum. 58. ed. rev. e ampl. Rio de Janeiro: Forense, 2017. v. 1.

VENTURI, Elton. Transação de direitos indisponíveis? Revista de Processo, São Paulo, v. 41, n. 251, p. 391-426, jan. 2016.

ZANETI JR., Hermes. Ativismo da lei e da constituição na tutela coletiva brasileira: processos estruturais, processos complexos e litígios de difusão irradiada. In: NUNES, Dierle; COSTA, Fabrício Veiga; GOMES, Magno Federici (Org.). Processo coletivo, desenvolvimento sustentável e a tutela diferenciada dos direitos fundamentais. Porto Alegre: Editora Fi, 2019. p. 407-428. 